\title{
Renal Pelvis Carcinoma
}

National Cancer Institute

\section{Source}

National Cancer Institute. Renal Pelvis Carcinoma. NCI Thesaurus. Code C6142.

A carcinoma arising in the renal pelvis. The majority of renal pelvis carcinomas are transitional cell and less frequently squamous cell carcinomas. 